\title{
INFLUENCE OF THE STRUCTURE OF AMINE COMPONENTS ON CARBOXYPEPTIDASE $Y$ CATALYZED AMIDE BOND FORMATION
}

\author{
by
}

FRED WIDMER, KLAUS BREDDAM and JACK T. JOHANSEN

Department of Chemistry, Carlsberg Laboratory

Gamle Carlsberg Vej 10, DK-2500 Copenhagen Valby Keywords: Enzymatic synthesis, peptide synthesis, carboxypeptidase Y, high pressure liquid
chromatography

Carboxypeptidase $\mathrm{Y}$ catalyzed reactions between a common acyl component (Bz-Ala-OMe) and a variety of amine compounds are described. The $\alpha$-amino acid amides tested were - with the exception of isoglutamine incorporated in high yields (70-95\%). For the free $\alpha$-amino acids, the yields were below $60 \%$ and fluctuated widely. For the cases examined, the enzyme only reacted with the L-enatiomers of these compounds. Dipeptides were not accepted as amine components. Glycinonitril, glycine- $\mathrm{N}$-methyl amide and threonine- $\mathrm{N}$-methyl amide reacted in low yields $(<20 \%)$ only. None of the secondary amines tested (sarcosine, sarcosine methyl ester, Nmethyl-alanine, proline and proline amide) was incorporated to form an amide bond. However, several structurally interesting primary amines (e.g., L-alaninol, cyclopropylamine, $\beta$-alanine amide, taurine etc.) reacted in good yields (40-60\%), indicating that carboxypeptidase $Y$ may also become useful for the synthesis of certain peptide analogues.

\footnotetext{
Abbreviations: $\mathrm{Bz}-=$ benzoyl, $\mathrm{CPD}-\mathrm{Y}=$ carboxypeptidase $\mathrm{Y}, \mathrm{HPLC}=$ high pressure liquid chromatography, Sar $=$ sarcosine, Taurine $=2$-aminoethanesulfonic acid, TEAF $=$ triethylammonium formate buffer, TEAP $=$ triethylammonium phosphate buffer. Amino acids abbreviated in upper case refer to the L-enantiomer and those in lower case refer to the D-enantiomer. Other abbreviations of amino acids, amino acid derivatives and peptides are according to the guidelines of the IUPAC-IUB Commission on Biochemical Nomenclature. The binding notation for the enzyme and the substrates is that of SCHECHTER and BERGER (16). Accordingly, amino acid residues in the substrate are referred to as $\mathrm{P}_{1}, \mathrm{P}_{2} \ldots \mathrm{P}_{\mathrm{i}}$ in the amino-terminal direction away from the scissible bond and $\mathrm{P} i$ for the carboxy-terminal residue that is hydrolyzed off. Enzyme subsites are denoted $\mathrm{S}_{1}$, $\mathrm{S}_{2} \ldots \mathrm{S}_{\mathrm{i}}$ and $\mathrm{S} \mathrm{i}$ in correspondence with the substrate.
} 


\section{INTRODUCTION}

Early work on endoprotease catalyzed peptide bond formation, as reviewed by FruToN (6), had primarily been motivated by the possible importance of such processes for in vivo protein synthesis. The more recent interest in these reactions stems from the desire to exploit proteolytic enzymes as catalysts for the formation of peptide bonds in peptide synthesis $(5,13$, $17)$ and protein semisynthesis $(7,8,11)$. Some proteolytic enzymes have also been used for $\mathrm{N}$ and C-terminal protecting group removal (10, $12,15)$.

In this laboratory we have investigated the potential of the serine carboxypeptidase from Saccharomyces cerevisiae, i.e., carboxypeptidase $\mathrm{Y}$, as a reagent for step-wise synthesis of peptides $(4,19,20)$ as well as for protein semisynthesis (3). The unique properties of this enzyme which make it a promising tool for synthetic purposes have been discussed $(3,19,21)$, and the dependence of the coupling yields on the structure of the N-protected amino acid esters or peptide esters used as acyl components has been described (4). The behaviour of amino acid alkyl esters as amine components in CPD-Y catalyzed peptide bond formation was also examined (20).

In the present paper we report results on the dependence of the coupling yields on the structure of a variety of other amine components, using Bz-Ala-OMe as the common acyl component. The majority of the reactions that were studied are summarized in Scheme 1.

\section{MATERIALS AND METHODS}

\subsection{Materials}

Carboxypeptidase $\mathrm{Y}$ from baker's yeast was isolated and used for peptide synthesis as described earlier (3, 19). L-Amino acids amides, leucinol hydrochlorid, D-alanine, D-valine, Dalanine amide hydrochloride, $\mathrm{N}$-benzoyl-tyrosine ethyl ester, $\mathrm{N}$-benzoyl-alanine methyl ester, $\mathrm{N}-\varepsilon$ CBZ-lysine methyl ester hydrochloride, H-Gly$\mathrm{NHCH}_{3}, \mathrm{H}-\mathrm{Thr}-\mathrm{NHCH}_{3}, \mathrm{H}-\mathrm{Glu}\left(\mathrm{O}^{\prime} \mathrm{Bu}\right)-\mathrm{OH}, \mathrm{H}-$ Gly-Gly-OH, H-Ala-Gly-OH and H-Leu-Gly$\mathrm{OH}$ were from Bachem AG, Bubendorf, Switzerland. D-Valine amide hydrochloride, $\beta$-alanine amide hydrochloride and threonine amide were from Vega-Fox Chemicals, Tucson, USA. Ethanolamine puriss was bought from Fluka AG, Buchs, Switzerland, and taurine $99 \%$ from EGA-Chemie, Steinheim, FRG. Glycinonitril hydrochloride, methylamine hydrochloride, ethylamine hydrochloride, diethylamine hydrochloride, benzylamine hydrochloride, cyclopropylamine, cyclopentylamine (all synthesis grade) and hydrazine sulfate, hydroxylamine hydrochloride, $25 \%$ ammonium hydroxide solution (all analytical grade) were from Merck, Darmstadt, FRG. L-Amino acids, $\beta$-alanine, $\beta$ alanine methyl ester, $S$-methyl cysteine, alaninol, 2-amino-ethyl phosphonic acid, glycine hydroxamic acid, leucine hydroxamic acid and alanine hydroxamic acid were obtained through Sigma Chemical Company, St. Louis, USA. The two solvents used for HPLC were: Methanol für die Chromatographie ("LiChrosolv«) from Merck, Darmstadt, FRG and Acetonitril HPLC Grade S from Rathburn Chemicals Ltd., Walkerburn, Peeblesshire, Scotland.

Asparagine amide was prepared from aspartic acid as described earlier (19). Lysine amide dihydrochloride was prepared from $\mathrm{N}-\varepsilon$-carbobenzoxy lysine amide (obtained from $\mathrm{N}-\varepsilon$-carbobenzoxy lysine methyl ester according to BERGMAN et al. (2)) by deprotection with dry $\mathrm{HCl}$ at $80^{\circ} \mathrm{C}$ as described by Levin et al. (9). The crude product was contaminated with benzyl chloride which was removed by trituration in warm methanol. The white powder thus obtained was filtered off and dried over $\mathrm{KOH}$-pellets. Yield: $50 \%$, m.p.: $213-216^{\circ} \mathrm{C}$, Lit.: $216-219^{\circ} \mathrm{C}(18)$.

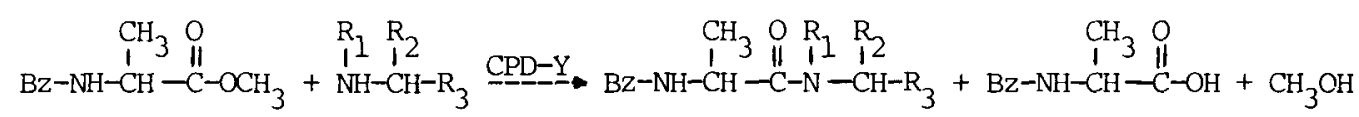

Scheme 1. CPD-Y catalyzed formation of amide bonds between Bz-Ala-OMe (acyl component) and a series of different amine components. $\mathbf{R}_{1}=-\mathrm{H},-\mathrm{CH}_{3} \cdot \mathrm{R}_{2}=-\mathrm{H}$, amino acid side chain. $\mathrm{R}_{3}=-\mathrm{COOH},-\mathrm{CONH}_{2}$, $-\mathrm{CONHOH},-\mathrm{CONHCH}_{3},-\mathrm{CONHCH}_{2} \mathrm{COOH},-\mathrm{H},-\mathrm{CH}_{3},-\mathrm{CH}_{2} \mathrm{OH},-\mathrm{CN},-\mathrm{CH}_{2} \mathrm{COOH},-\mathrm{CH}_{2} \mathrm{SO}_{3} \mathrm{H}$, $-\mathrm{CH}_{2} \mathrm{PO}_{3} \mathrm{H}_{2}$. 


\subsection{Methods}

All CPD-Y catalyzed reactions were performed in small scale $(2-4 \mathrm{ml})$ using a pH-stat as described in detail previously $(3,4,19,20)$. Aliquots of the reaction mixture were quenched into a ten-fold excess of $\mathrm{CH}_{3} \mathrm{CN}$ and analyzed by HPLC. Whenever the quenched samples were biphasic, they were diluted with water and/or ethanol to produce homogeneous solutions.

The Waters liquid chromatography system used consisted of a Model U6K injector, two Model 6000A pumps, a Model 660 solvent programmer, a Model 450 UV-detector, A Waters Date Module and a Waters Radial Compression Module (RCM-100) housing a Waters Radial Pak A (reverse-phase) column. As eluants were used $25 \mathrm{~mm}$ and $50 \mathrm{~mm}$-TEAP or TEAF buffers, pH 3.0 and methanol or acetonitril. Buffers and solvents were filtered and degassed daily. All separations were carried out at room temperature and were monitored at 254 $\mathrm{nm}$. Available gradient programs (mostly linear No. 6 and concave No. 7) and flow-rates between 2.5 and $5.0 \mathrm{ml} \cdot \mathrm{min}^{-1}$ allowed all desired separations to be carried out in 5-15 minutes. Four representative examples, together with detailed chromatographic conditions, are shown in Figure 1.

The reactants were identified by cochromatography with authentic samples and by peak collection followed by amino acid analysis. In some reactions the products were identified by inference. For example, in the reaction between Bz-Ala-OMe and $\mathrm{NH}_{2} \mathrm{CH}_{2} \mathrm{CH}_{2} \mathrm{OH}$ three peaks were observed, and one of them was assigned to $\mathrm{Bz}$-Ala- $\mathrm{NHCH}_{2} \mathrm{CH}_{2} \mathrm{OH}$ since the two others were identified by cochromatography as Bz-Ala$\mathrm{OH}$ and Bz-Ala-OMe. Complete elution of all products was ensured by comparing the peak area of the zero-time sample with the sum of the

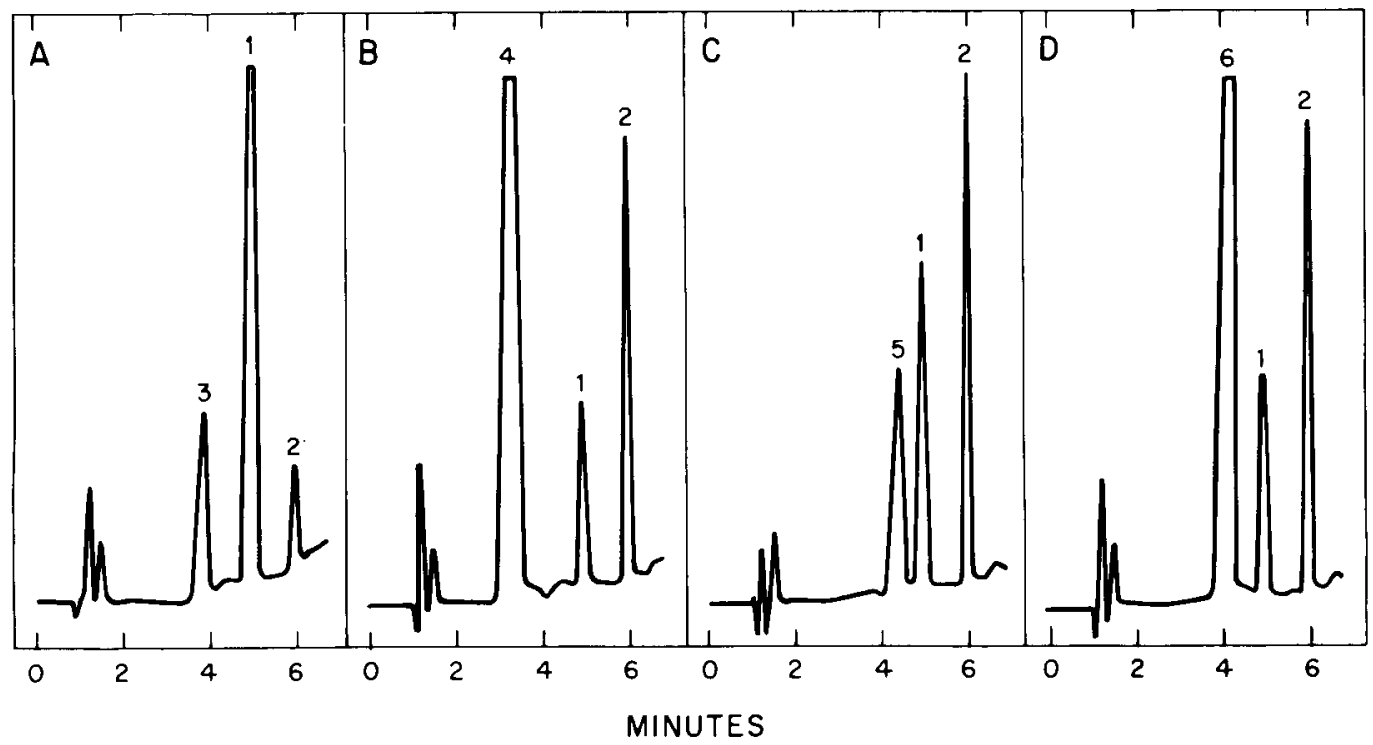

Figure 1. HPLC chromatograms of compounds formed by CPD-Y catalyzed reactions between Bz-Ala-OMe and

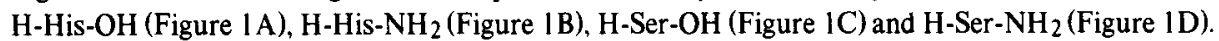

Experimental conditions are given in Table I. At $3 \mathrm{~min}, 100 \mu \mathrm{l}$ aliquots were quenched into $1 \mathrm{ml} \mathrm{CH}_{3} \mathrm{CN}$ which was mixed with $1 \mathrm{ml} \mathrm{H} 20$ prior to separation of $50 \mu \mathrm{l}$ on a Waters Radial Pak A column using Waters HPLC equipment described in section 2. The eluants were: $\mathrm{A}=50 \mathrm{~mm}-\mathrm{TEAF}, \mathrm{pH} 3.0 ; \mathrm{B}=80 \%(\mathrm{v} / \mathrm{v})$ $\mathrm{MeOH} / 20 \%(\mathrm{v} / \mathrm{v}) 50 \mathrm{~mm}-\mathrm{TEAF}, \mathrm{pH} 3.0$. The linear gradient (No. 6) was used: from $20 \%$ to $100 \% \mathrm{~B}$ in 6 min. Other parameters were as follows. Flow: $3 \mathrm{ml} \cdot \mathrm{min}^{-1}$; column pressure: $800-1000$ psi; room temperature; chart speed $0.5 \mathrm{~cm} \cdot \mathrm{min}^{-1}$. The ordinate shows the absorbance at $254 \mathrm{~nm}$ with a detector sensitivity of 0.4 AUFS. By cochromatography with Bz-Ala-OH and Bz-Ala-OMe, and by collection of peaks and amino acid analysis the following peak assignments were made: $1=\mathrm{Bz}-\mathrm{Ala}-\mathrm{OH} ; 2=\mathrm{Bz}-\mathrm{Ala}-\mathrm{OMe} ; 3=\mathrm{Bz}-\mathrm{Ala}-\mathrm{His}-\mathrm{OH}$; 4 = Bz-Ala-His- $\mathrm{NH}_{2} ; 5$ = Bz-Ala-Ser-OH; 6 = Bz-Ala-Ser-NH 2 . 
areas of all peaks observed at later times. In this fashion the formation of $\mathrm{Bz}-\mathrm{Ala}-\mathrm{OCH}_{2} \mathrm{CH}_{2} \mathrm{NH}_{2}$ as a conceivable minor product could be excluded.

The product yields are accurate to $\pm 5 \%$ and were calculated from the peak areas based on the absorbance of the dominant chromophore $\mathrm{C}_{6} \mathrm{H}_{5}$ $\mathrm{CO}-\mathrm{NH}-(\mathrm{N}-\mathrm{Bz}-)$ at $254 \mathrm{~nm}$.

\section{RESULTS}

The purpose of the experiments described in the present paper was to investigate the dependence of the synthesis yields in CPD-Y catalyzed amide bond formation on the structure of the amine component. Bz-Ala-OMe was used as the common acyl component.

Table I summarizes the yields observed with free amino acids and amino acid amides and allows a comparison between these two groups of amine components. As indicated by a less complete series of experiments reported earlier (19), it is evident that amino acid amides are incorporated in significantly higher yields (70$95 \%)$ than free amino acids (10-60\%). In addition, with the exception of isoglutamine, the yields among amino acid amides depend little on the structure of the side chain. However, for free amino acids the nature of the side chain exerts a pronounced effect on the yields. It should be

\section{Table I}

Influence of the side chain structure of amino acids and amino acid amides on yields of CPD-Y catalyzed peptide bond formation.

Bz-Ala-OMe was the common substrate used. Yields are given for formation of Bz-Ala-AA-OH and Bz-AlaAA- $\mathrm{NH}_{2}$, respectively.a), c)

\begin{tabular}{|c|c|c|c|}
\hline $\begin{array}{l}\alpha \text {-L-amino acids as } \\
\text { amine components }\end{array}$ & yields, $\%$ & $\begin{array}{l}\alpha \text {-L-amino acid amides } \\
\text { as amine components }\end{array}$ & yields, $\%$ \\
\hline Glycine $(3.0 \mathrm{M})$ & 60 & Glycine amide $(0.3 \mathrm{M})$ & 90 \\
\hline Alanine $(1.5 \mathrm{~m})$ & 65 & Alanine amide $(0.25 \mathrm{M})$ & 80 \\
\hline Serine $(3.0 \mathrm{M})$ & 50 & Serine amide $(0.3 \mathrm{M})$ & 90 \\
\hline S-Methyl-Cysteine $(0.25 \mathrm{M})$ & 60 & & \\
\hline Valine $(0.6 \mathrm{M})$ & 40 & Valine amide $(0.4 \mathrm{M})$ & 95 \\
\hline Threonine $(0.7 \mathrm{~m})$ & 25 & Threonine amide $(0.2 \mathrm{M})$ & 85 \\
\hline Isoleucine $(0.15 \mathrm{M})$ & 40 & Isoleucine amide $(0.3 \mathrm{M})$ & $85^{b)}$ \\
\hline Leucine $(0.17 \mathrm{M})$ & 25 & Leucine amide $(0.3 \mathrm{M})$ & $85 \mathrm{~b})$ \\
\hline Methionine $(0.6 \mathrm{M})$ & 45 & Methionine amide $(0.5 \mathrm{M})$ & $95 \mathrm{~b})$ \\
\hline Lysine (1.5 M) & 55 & Lysine amide $(0.25 \mathrm{~m})$ & 70 \\
\hline Arginine $(0.8 \mathrm{M})$ & 30 & & \\
\hline Glutamic acid (1.2 M) & 0 & Isoglutamine $(0.25 \mathrm{M})$ & 0 \\
\hline Glutamine $(0.5 \mathrm{M})$ & 20 & Glutamine amide $(0.5 \mathrm{M})$ & 90 \\
\hline H-Glu(OMe)-OH (0.5 M) & 35 & & \\
\hline $\mathrm{H}-\mathrm{Glu}(\mathrm{O} \mathrm{tBu})-\mathrm{OH}(0.5 \mathrm{M})$ & 25 & $\mathrm{H}-\mathrm{Glu}\left(\mathrm{O}^{\mathrm{t}} \mathrm{Bu}\right)-\mathrm{NH}_{2}(0.2 \mathrm{~m})$ & 95 b) \\
\hline Aspartic acid $(1.0 \mathrm{M})$ & 0 & & \\
\hline Asparagine $(0.6 \mathrm{M})$ & 20 & Asparagine amide $(0.3 \mathrm{M})$ & 80 \\
\hline H-Asp $\left(\mathrm{O}^{\mathrm{t} B u}\right)-\mathrm{OH}(0.5 \mathrm{M})$ & 30 & $\mathrm{H}-\mathrm{Asp}\left(\mathrm{O}^{\prime} \mathrm{Bu}\right)-\mathrm{NH}_{2}(0.2 \mathrm{M})$ & $85^{b)}$ \\
\hline Phenylalanine $(0.15 \mathrm{~m})$ & 25 & Phenylalanine amide $(0.3 \mathrm{M})$ & $90^{\mathrm{b})}$ \\
\hline Tyrosine & - d) & Tyrosine amide $(0.5 \mathrm{M})$ & 90 \\
\hline Tryptophane $(0.05 \mathrm{M})$ & 10 & Tryptophane amide $(0.2 \mathrm{M})$ & $85^{b)}$ \\
\hline Histidine $(1.0 \mathrm{M})$ & 15 & Histidine amide $(0.2 \mathrm{M})$ & 85 \\
\hline
\end{tabular}

a) Conditions: $50 \mathrm{~mm}$-Bz-Ala-OMe, $0.1 \mathrm{~m}-\mathrm{KCl}, 1 \mathrm{~mm}$-EDTA, $10 \% \mathrm{CH}_{3} \mathrm{OH}, \mathrm{pH} 9.5,20-25^{\circ} \mathrm{C}, 4-8 \mu \mathrm{M}$ CPD-Y. Reactions were quenched after 10 min and evaluated by HPLC as described in section 2 .

b) Products partially precipitated.

c) Previous CPD-Y preparations had not been entirely free of contamination by endoproteolytic activity and thus several values reported here are higher than those obtained previously (19).

d) The solubility of tyrosine is too low for the purpose of these experiments. 
Table II

Stereospecificity of CPD-Y catalyzed peptide bond formation with respect to the D and $\mathrm{L}$ forms of the amine components alanine, valine and valine amide.a)

\begin{tabular}{|c|c|c|c|}
\hline Acyl component & Amine component & Products formed & Yield, \% \\
\hline \multirow[t]{6}{*}{ Bz-Ala-OMe } & $\mathrm{H}-\mathrm{Val}-\mathrm{OH}$ & $\mathrm{Bz}-\mathrm{Ala}-\mathrm{OH}$ & 60 \\
\hline & & Bz-Ala-Val-OH & 40 \\
\hline & $\mathrm{H}$-val-OH & $\mathrm{Bz}-\mathrm{Ala}-\mathrm{OH}$ & 100 \\
\hline & H-Ala-OH & Bz-Ala-OH & 35 \\
\hline & & Bz-Ala-Ala-OH & 65 \\
\hline & $\mathrm{H}$-ala-OH & Bz-Ala-OH & 100 \\
\hline \multirow[t]{6}{*}{ Bz-Tyr-OEt } & $\mathrm{H}-\mathrm{Val}-\mathrm{OH}$ & $\mathrm{Bz}-\mathrm{Tyr}-\mathrm{OH}$ & 70 \\
\hline & & Bz-Tyr-Val-OH & 30 \\
\hline & $\mathrm{H}$-val-OH & Bz-Tyr-OH & 100 \\
\hline & $\mathrm{H}-\mathrm{Ala}-\mathrm{OH}$ & $\mathrm{Bz}-\mathrm{Tyr}-\mathrm{OH}$ & 55 \\
\hline & & Bz-Tyr-Ala-OH & 45 \\
\hline & $\mathrm{H}$-ala-OH & Bz-Tyr-OH & 100 \\
\hline \multirow[t]{3}{*}{ Bz-Ala-OMe } & $\mathrm{H} \cdot \mathrm{Val}-\mathrm{NH}_{2}$ & Bz-Ala-OH & 20 \\
\hline & & Bz-Ala-Val-NH ${ }_{2}$ & 80 \\
\hline & $\mathrm{H}$-val- $\mathrm{NH}_{2}$ & Bz-Ala-OH & 100 \\
\hline \multirow[t]{3}{*}{$\mathrm{Bz}-\mathrm{Tyr}-\mathrm{OEt}$} & $\mathrm{H}-\mathrm{Val}-\mathrm{NH}_{2}$ & Bz-Tyr-OH & 5 \\
\hline & & Bz-Tyr-Val- $\mathrm{NH}_{2}$ & $95^{b)}$ \\
\hline & $\mathrm{H}$-val- $\mathrm{NH}_{2}$ & Bz-Tyr-OH & 100 \\
\hline
\end{tabular}

a) Conditions: $50 \mathrm{~mm}-\mathrm{Bz}-\mathrm{Ala}-\mathrm{OMe} ; 10 \mathrm{~mm}-\mathrm{Bz}-\mathrm{Tyr}-\mathrm{OEt}$. Valine was $0.5 \mathrm{M}$, alanine was $1.5 \mathrm{M}$ and valine amide was 0.25 м. pH $9.5,20-25{ }^{\circ} \mathrm{C}, 0.1 \mathrm{~m}-\mathrm{KCl}, 1 \mathrm{~mm}-\mathrm{EDTA}, 10 \% \mathrm{CH}_{3} \mathrm{OH}, 4 \mu \mathrm{M} \mathrm{CPD}-\mathrm{Y}$. Reactions were quenched after 10 min and evaluated by HPLC as described in section 2.

b) Product partially precipitated.

noted that the concentrations reported in Table I for the amino acids were optimized for maximal yields, i.e. in most cases they are saturating concentrations.

The stereoselectivity of aminolysis of the acylenzyme by amino acids and amino acid amides is presented in Table II. For the cases examined, only the L-enantiomers seem to result in aminolysis and amide bond formation. These experiments also showed that D-enantiomers do not significantly inhibit the turnover rate of the acyl component. It should thus be possible to use racemic amino acids and amino acid amides as amine components, and to isolate the remaining D-enantiomers.

Supplementing earlier work with $\alpha$-amino acid alkyl esters (20), additional carbonyl substituted $\alpha$-amino carbonyl compounds were examined as amine components (Table III). The dipeptides that were tested were found not to react at all, and the $\mathrm{N}$-methyl amides of glycine and threonine resulted in poor coupling yields $(<20 \%)$. For amino acid hydroxamates, the yields depended on the size of the side chain, i.e., glycine hydroxamate was incorporated to $75 \%$, alanine hydroxamate to $50 \%$ and leucine hydroxamate not at all. These results thus indicate that productive binding of the amine component to the acyl-enzyme depends crucially on the structure of the carbonyl substituents. (Here, "productive binding « is used with reference to subsequent amide bond formation rather than amide bond cleavage).

In an attempt to enhance the peptidolytic stability of peptides, it is often desirable to prepare peptide analogues with an unusual amino acid at the $\mathrm{C}$-terminal. For this reason we examined as amine components a series of 


\section{Table III}

CPD-Y catalyzed amide bond formation using BzAla-OMe as common acyl component and amine components having an $\alpha$-amino carbonyl configuration as common structural feature.a)

\begin{tabular}{|c|c|c|}
\hline $\begin{array}{l}\text { Amine } \\
\text { component }\end{array}$ & Aminolysis product & Yield, $\%$ \\
\hline H-Gly-NHOH & Bz-Ala-Gly-NHOH & $75^{b)}$ \\
\hline H-Ala-NHOH & Bz-Ala-Ala-NHOH & $50^{b)}$ \\
\hline H-Leu-NHOH & Bz-Ala-Leu-NHOH & $0^{c)}$ \\
\hline $\mathrm{H}-\mathrm{Gly}-\mathrm{NHCH}_{3}$ & Bz-Ala-Gly-NHCH 3 & $12^{\mathrm{d})}$ \\
\hline $\mathrm{H}-\mathrm{Thr}-\mathrm{NHCH}_{3}$ & Bz-Ala-Thr-NHCH 3 & $<10$ \\
\hline H-Gly-Gly-OH & Bz-Ala-Gly-Gly-OH & 0c) \\
\hline H-Ala-Gly-OH & Bz-Ala-Ala-Gly-OH & $0^{c)}$ \\
\hline H-Leu-Gly-OH & Bz-Ala-Leu-Gly-OH & $0^{c)}$ \\
\hline
\end{tabular}

a) Reactions were performed in a pH-stat, quenched after $15-30 \mathrm{~min}$ and evaluated by HPLC as described in section 2 . Conditions: $50 \mathrm{~mm}-\mathrm{Bz}$-AlaOMe, 0.1 м-KCl, 1 mм-EDTA, $10 \% \mathrm{CH}_{3} \mathrm{OH}$, $\mathrm{pH} 9.5, \quad 20-25^{\circ} \mathrm{C}, 4.5 \mu \mathrm{M}-\mathrm{CPD}-\mathrm{Y}$. Amine components were $0.25 \mathrm{M}$.

b) Only one new compound was formed in addition to Bz-Ala-OH. It was isolated and shown to be ninhydrin negative on TLC.

c) Only rapid and complete hydrolysis to Bz-Ala-OH was observed

d) At $0.5 \mathrm{M}-\mathrm{H}-\mathrm{Gly}-\mathrm{NHCH}_{3}$, the yield was $20 \%$.

amines that are lacking the $\alpha$-amino carbonyl configuration shared by all derivatives of $\alpha$ amino acids (Table IV). The data indicate that CPD-Y can catalyze the formation of amide bonds with a wide range of such compounds provided the $\mathrm{pK}_{\mathrm{a}}$ of the amino group is at or below the $\mathrm{pH}$ at which the reactions are carried out ( $\mathrm{pH}$ 9.5). If the amine is sufficiently soluble, a seemingly unfavorable $\mathrm{pK}_{\mathrm{a}}$ can be compensated for by increasing the concentration, provided the amine component does not significantly inhibit the formation of the acyl-enzyme as for instance was observed with benzylamine. Secondary amines as in proline- or sarcosine derivatives are not incorporated at all, even if the $\mathrm{pK}_{\mathrm{a}}$ of the secondary amine is one unit below the reaction$\mathrm{pH}$, as is the case with sarcosine methyl ester $\left(\mathrm{pK}_{\mathrm{a}} 8.4\right)$ for example.

\section{DISCUSSION}

In analogy to a wide variety of endoproteases (reviewed in 5 and 6), the serine carboxypeptidase from baker's yeast (CPD-Y) was found to catalyze the formation of amide bonds $(5,19)$. Coupling reactions between $\mathrm{N}$-protected amino acid- or peptide alkyl esters (acyl components) and suitable amines (amine components) proceeds in two steps. In the first step, the acyl component reacts with the enzyme to form an acyl-enzyme intermediate. In the second step, this »active ester « intermediate reacts either with water to form a carboxylic acid (hydrolysis product) or with the competing amine component to form an amide (aminolysis product). The yield of aminolysis depends on the nucleophilicity of the amino group of the amine component, its concentration, and on the spatial orientation in the wacyl-enzyme/amine component" complex of the carbonyl group of the acyl moiety and the amino group of the amine component.

In our studies aimed at elucidating the potential of CPD-Y as a catalyst in peptide synthesis, we have recently examined the influence of the structure of the acyl component on the yields of aminolysis $(3,4)$. The influence of the structure of amine components was so far only investigated with amino acid alkyl esters (20). The dependence of the yields on the structure of various other amines is described in the present paper.

In agreement with earlier results $(4,19)$, the data indicate that amino acid amides are the most efficient amine components in CPD-Y catalyzed transacylation reactions. With the notable exception of isoglutamine and proline amide (vide infra), the yields were high (70-95\%) and rather independent of the structure of the side chain. For no other group of amine components that was tested (amino acids, amino acid hydroxamates, amino acid $\mathrm{N}$-methyl amides, primary and secondary amines, imines) were the yields as high and similarly independent of the side chain structure. The low $\mathrm{pK}_{\mathrm{a}}\left(\alpha-\mathrm{NH}_{2}\right)$ value of amino acid amides does not by itself explain the high yields obtained, since the $\mathrm{pK}_{\mathrm{a}}$ values of amino acid methyl esters, amino acid hydroxamates and amino acid $\mathrm{N}$-methyl amides are equally low but the coupling yields are lower than those for the corresponding amides. An explanation for the uniqueness of amino acid amides as amine components may be based on the observation 
Table IV

CPD-Y catalyzed amide bond formation using Bz-Ala-OMe as common acyl component and various primary and secondary amines as amine components.a)

\begin{tabular}{|c|c|c|c|}
\hline Amine components & $\mathrm{pK}_{\mathrm{a}}\left(\alpha-\mathrm{NH}_{2}\right)^{\mathrm{b})}$ & Aminolysis products & Yields, $\%$ c) \\
\hline $\mathrm{NH}_{3}(1.0 \mathrm{M})$ & 9.4 & $\mathrm{Bz}-\mathrm{Ala}-\mathrm{NH}_{2}$ & 15 \\
\hline $\begin{array}{c}(4.0 \mathrm{~m}) \\
\mathrm{NH}_{2} \mathrm{NH}_{2}(1.0 \mathrm{~m})\end{array}$ & 8.1 & $\mathrm{Bz}-\mathrm{Ala}-\mathrm{NHNH}_{2}$ & $\begin{array}{l}60 \\
45\end{array}$ \\
\hline $\mathrm{NH}_{2} \mathrm{OH}(1.0 \mathrm{M})$ & 6.0 & Bz-Ala-NHOH & 60 \\
\hline $\mathrm{CH}_{3} \mathrm{NH}_{2}(1.0 \mathrm{M})$ & 10.6 & $\mathrm{Bz}-\mathrm{Ala}-\mathrm{NHCH}_{3}$ & $<10$ \\
\hline $\mathrm{C}_{2} \mathrm{H}_{5} \mathrm{NH}_{2}(1.0 \mathrm{M})$ & 10.6 & Bz-Ala- $\mathrm{NHC}_{2} \mathrm{H}_{5}$ & $<10$ \\
\hline Benzylamine $(0.1 \mathrm{M}) \mathrm{d})$ & 9.3 & Bz-Ala- $\mathrm{NHCH}_{2} \mathrm{C}_{6} \mathrm{H}_{5}$ & 65 \\
\hline$\left(\mathrm{C}_{2} \mathrm{H}_{5}\right)_{2} \mathrm{NH}(1.0 \mathrm{M})$ & 10.8 & Bz-Ala- $\mathrm{N}\left(\mathrm{C}_{2} \mathrm{H}_{5}\right)_{2}$ & 0 \\
\hline H-Sar-OH $(0.5 \mathrm{~m})$ & 10.1 & Bz-Ala-Sar-OH & 0 \\
\hline H-Sar-OMe $(0.5 \mathrm{~m})$ & $8.4 \mathrm{e})$ & Bz-Ala-Sar-OX $\left(\mathrm{X}=\mathrm{H}, \mathrm{CH}_{3}\right)$ & 0 \\
\hline N-Me-Ala-OH (0.5 M) & 10.2 & Bz-Ala-N $\left(\mathrm{CH}_{3}\right)$-Ala-OH & 0 \\
\hline H-Pro-OH (0.5 м) & 10.6 & Bz-Ala-Pro-OH & 0 \\
\hline H-Pro- $\mathrm{NH}_{2}(0.25 \mathrm{M})$ & $8.8^{\circ}$ & Bz-Ala-Pro-NH 2 & 0 \\
\hline $\mathrm{H}-\mathrm{Gly}-\mathrm{CN}(0.2 \mathrm{M})$ & 5.3 & Bz-Ala-NHCH ${ }_{2} \mathrm{CN}$ & 0 \\
\hline$(2.0 \mathrm{M})$ & & $"$ & $30 \mathrm{~g})$ \\
\hline $\mathrm{NH}_{2} \mathrm{CH}_{2} \mathrm{CH}_{2} \mathrm{OH}(0.2 \mathrm{M})$ & 9.5 & $\mathrm{Bz}-\mathrm{Ala}-\mathrm{NHCH}_{2} \mathrm{CH}_{2} \mathrm{OH}$ & 25 \\
\hline$(2.0 \mathrm{M})$ & & $»$ & 40 \\
\hline $\mathrm{H}-\mathrm{Ala}-\mathrm{CH}_{2} \mathrm{OH}(0.5 \mathrm{M})$ & 9.4 & Bz-Ala-Ala- $\mathrm{CH}_{2} \mathrm{OH}$ & 55 \\
\hline H-Leu- $\mathrm{CH}_{2} \mathrm{OH}(0.2 \mathrm{M})$ & & Bz-Ala-Leu- $\mathrm{CH}_{2} \mathrm{OH}$ & 20 \\
\hline $\mathrm{H}-\beta$-Ala-OH $(0.5 \mathrm{~m})$ & 10.2 & Bz-Ala- $\beta$-Ala-OH & 0 \\
\hline \multirow[t]{2}{*}{$\mathrm{H}-\beta-\mathrm{Ala}-\mathrm{OMe}(0.5 \mathrm{M})$} & $9.2 \mathrm{el}$ & Bz-Ala- $\beta$-Ala-OMe & 45 \\
\hline & & Bz-Ala- $\beta$-Ala-OH & 5 \\
\hline $\mathrm{H}-\hat{\beta}-\mathrm{Ala}-\mathrm{NH}_{2}(0.2 \mathrm{~m})$ & & $\mathrm{Bz}-\mathrm{Ala}-\hat{\beta}-\mathrm{Ala}-\mathrm{NH}_{2}$ & 80 \\
\hline $\mathrm{NH}_{2} \mathrm{CH}_{2} \mathrm{CH}_{2} \mathrm{SO}_{3} \mathrm{H}(0.5 \mathrm{M})$ & 8.9 & $\mathrm{Bz}-\mathrm{Ala}-\mathrm{NHCH}_{2} \mathrm{CH}_{2} \mathrm{SO}_{3} \mathrm{H}$ & 45 \\
\hline $\mathrm{NH}_{2} \mathrm{CH}_{2} \mathrm{CH}_{2} \mathrm{PO}_{3} \mathrm{H}_{2}(0.2 \mathrm{M})$ & & Bz-Ala- $\mathrm{NHCH}_{2} \mathrm{CH}_{2} \mathrm{PO}_{3} \mathrm{H}_{2}$ & 60 \\
\hline 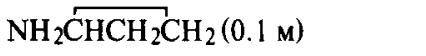 & $\sim 8.5^{\mathrm{h})}$ & Bz-Ala-NHC $\overparen{\mathrm{CHCH}_{2}} \mathrm{CH}_{2}$ & 45 \\
\hline $\mathrm{NH}_{2} \mathrm{CHCH}_{2} \mathrm{CH}_{2} \mathrm{CH}_{2} \mathrm{CH}_{2}(1,0 \mathrm{M})$ & $\sim 8.5 \mathrm{hl}$ & 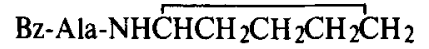 & $<10$ \\
\hline
\end{tabular}

a) For reaction conditions, cf. Table III.

b) With the exception of the values indicated under e), $f$ and $h$ ), the $\mathrm{pK}_{\mathrm{a}}$ values are from the Handbook of Biochemistry and Molecular Biology, ed. C. D. Fasman, Vol. 1. 3rd. ed.. CRC Press Inc., 1976.

c) In control experiments the extent of nonenzymatic amide formation was determined and found to be $<5 \%$ of the total yields listed. At $10 \mathrm{M}-\mathrm{NH}_{3}$ (where total yield was $85 \%$ ) nonenzymatic synthesis was $10-15 \%$.

d) At $0.5 \mathrm{~m}$ benzylamine, there was no turnover of Bz-Ala-OMe within the period of observation.

e) From Beilstein, Handbuch der Organischen Chemie, Vol. 4, 4. Erg. werk (1980).

f) From Beilstein, Vol. 22, 3./4. Erg. werk (1979).

g) After acid hydrolysis, the amino acid composition was: Ala 1.0, Gly 1.I.

h) The $\mathrm{pK}_{\mathrm{a}}$ of cyclic alkyl amines is approx. $2 \mathrm{pH}$ units lower than that of the corresponding $\mathrm{n}$-alkyl amines (cf. ref. 14).

that CPD-Y cleaves off amino acid amides from peptide C-terminals, i.e. has peptidyl-aminoacid-amide hydrolase activity (cf. Figure 2A), at pH 9-10 where its peptidase activity is minimal (3). The yield of aminolysis is not necessarily a consequence of the strength of binding of the amine component to the $\mathbf{S}$-binding region of the acyl-enzyme, but rather a consequence of the correctness of binding for subsequent acyltransfer and amide bond formation. Thus, if the aminolysis of the acyl-enzyme by amino acid amides (Figure 2B) corresponds to a reversed reaction sequence, it can be expected that the $>S_{i}$ carboxylate binding region (Figure 2) would be capable of binding amino acid amides more wcorrectly « than other amine components. Moreover, 

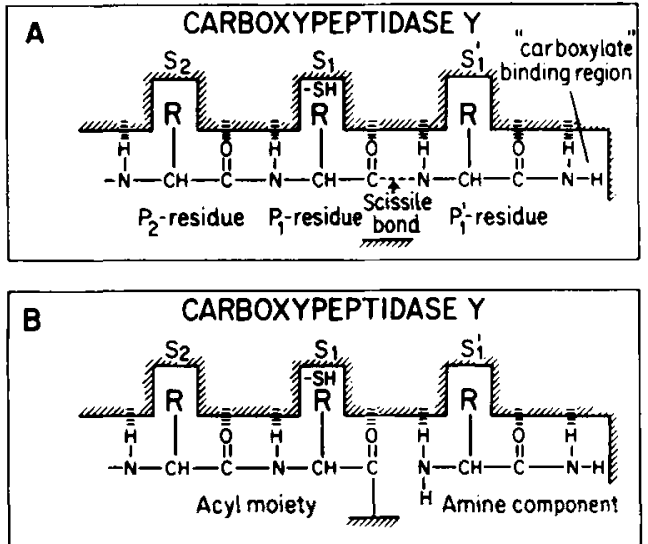

Figure 2. Schematic presentation of catalytic and binding regions of CPD-Y at $\mathrm{pH}$ 9-10 where peptidase activity is minimal. (At lower $\mathrm{pH}$, a residue in the wcarboxylate binding region « is presumably positively charged, ensuring binding of the $\mathrm{C}$ terminal carboxylate group of peptide substrates). The catalytic mode of the enzyme as depicted in Figure 2A, and indicated by the scissible bond (----), corresponds to its peptidyl-amino-acid-amide hydrolase activity (3); Figure 2B depicts the racyl-enzyme amino acid amider complex prior to amide bond formation. Evidence for the presence of a sulfhydryl group at the $\mathrm{S}_{1}$-binding subsite is reported by $\mathrm{BAY}_{\mathrm{A}}$ and HAYASHI (1).

under such special circumstances it may well be the case that binding of an amino acid amide at the "S $\mathbf{S}_{\text {-carboxylate }}$ site will affect the spatial orientation of the acyl component at the $S_{1}$ site in such a way as to position its carbonyl group in an optimal alignment for amide bond formation. It is important to note that the peptidyl-aminoacid-amide hydrolase activity towards the amide product is low compared to the esterase activity towards the initial ester substrate. The peptide amide product will thus accumulate and can be isolated after inactivation or removal of the enzyme.

Some of the structural characteristics responsible for the unique binding of amino acid amides to the "Si-carboxylater region of CPD-Y can be deduced from the yields observed with the glycine related amine components summarized in Table V. Although the $\mathrm{pK}_{\mathrm{a}}\left(\alpha-\mathrm{NH}_{2}\right)$ of H-Gly$\mathrm{OMe}, \mathrm{H}-\mathrm{Gly}-\mathrm{NH}_{2}$ and $\mathrm{H}-\mathrm{Gly}-\mathrm{NHOH}$ are very similar, the yields vary. In addition, the yield for
Table V

Efficiency of glycine related amine components as acyl acceptors in CPD-Y catalyzed transacylations using Bz-Ala-OMe as acyl component.a)

\begin{tabular}{|c|c|c|}
\hline Amine components & $\begin{array}{c}\mathrm{pK}_{\mathrm{a}} \\
\left(\mathrm{a}-\mathrm{NH}_{2}\right)^{\mathrm{b})}\end{array}$ & $\begin{array}{l}\text { Yield, } \\
\% \text { c) }\end{array}$ \\
\hline $\mathrm{NH}_{2} \mathrm{CH}_{2} \mathrm{COOH}(3.0 \mathrm{M})$ & 9.6 & 60 \\
\hline $\mathrm{NH}_{2} \mathrm{CH}_{2} \mathrm{CONH}_{2}(0.3 \mathrm{M})$ & 8.0 & 90 \\
\hline $\mathrm{NH}_{2} \mathrm{CH}_{2} \mathrm{CONHOH}(0.25 \mathrm{M})$ & & 75 \\
\hline $\mathrm{NH}_{2} \mathrm{CH}_{2} \mathrm{CONHCH}_{3}(0.25 \mathrm{M})$ & & 10 \\
\hline $\mathrm{NH}_{2} \mathrm{CH}_{2} \mathrm{CH}_{2} \mathrm{CONH}_{2}(0.2 \mathrm{M})$ & & 80 \\
\hline $\mathrm{NH}_{2} \mathrm{CH}_{2} \mathrm{CONHCH}_{2} \mathrm{COOH}(0.25 \mathrm{M})$ & 8.1 & 0 \\
\hline $\mathrm{NH}_{2} \mathrm{CH}_{2} \mathrm{CN}(2.0 \mathrm{M})$ & 5.3 & 30 \\
\hline $\mathrm{NH}_{2} \mathrm{CH}_{2} \mathrm{COOCH}_{3}(0.5 \mathrm{M})$ & 7.8 & $50^{d)}$ \\
\hline $\mathrm{NH}_{2} \mathrm{CH}_{2} \mathrm{COOCH}_{2} \mathrm{CH}_{3}(0.5 \mathrm{~m})$ & 7.8 & $95^{d)}$ \\
\hline $\mathrm{NH}_{2} \mathrm{CH}_{2} \mathrm{CH}_{2} \mathrm{OH}(0.2 \mathrm{M})$ & 9.5 & 40 \\
\hline $\mathrm{NH}\left(\mathrm{CH}_{3}\right) \mathrm{CH}_{2} \mathrm{COOH}(0.5 \mathrm{~m})$ & 10.1 & 0 \\
\hline $\mathrm{NH}\left(\mathrm{CH}_{3}\right) \mathrm{CH}_{2} \mathrm{COOCH}_{3}(0.5 \mathrm{M})$ & 8.4 & 0 \\
\hline
\end{tabular}

a) For reaction conditions cf. Table I-IV.

b) For sources of $\mathrm{pK}_{\mathrm{a}}$ values $\mathrm{cf}$. Table IV.

c) The yields refer to the formation of e.g., Bz-Ala$\mathrm{Gly}-\mathrm{OH}$, or Bz-Ala-Gly-NHCH , etc.

d) Data from ref. 20.

$\mathrm{H}-\mathrm{Gly}-\mathrm{NHOH}$ is higher than for H-Gly-OH although both have a negatively charged $\mathrm{C}$ terminal at $\mathrm{pH} 9.5$ where the aminolysis yields are determined. (A difference in effective amine concentration due to the higher $\mathrm{pK}_{\mathrm{a}}$ of glycine is compensated for by its ten-fold higher concentration). Since these molecules are sterically not drastically different, an explanation for the different yields may be sought in the different polarities of a carbonyl group in an amide, an acid or a hydroxamate. If optimal spatial orientation of the carbonyl group of the acyl moiety and the amino group of the amine component depended crucially on hydrogen bonding of this carbonyl oxygen to the enzyme, a change in polarity of this group might indeed be expected to exert a profound influence on the yields. This hypothesis is further supported by the result obtained with $\mathrm{H}-\mathrm{Gly}-\mathrm{NHCH}_{3}$, the structure of whose cis-isomer is not very different from that of $\mathrm{H}$-Gly-OEt or $\beta$-Ala- 
$\mathrm{NH}_{2}$.Nevertheless, $\mathrm{H}-\mathrm{Gly}-\mathrm{NHCH}_{3}$ gives a much lower coupling yield than the two others. This may be due to the fact that the polarity of its carbonyl group is different from that of an amide or an ester because of the inductive effect of the methyl group.

It is also apparent from the data in Table $\mathrm{V}$ that sterical restrictions exist at the $n \mathrm{~S}_{\mathrm{i}}$-carboxylate binding region of CPD-Y, since no coupling is obtained with dipeptides. However, the very low yield with $\mathrm{H}-\mathrm{Gly}-\mathrm{CN}$ is certainly not due to sterical hindrance nor due to an unfavorably high $\mathrm{pK}_{\mathrm{a}}$. On the contrary, here the $\mathrm{pK}_{\mathrm{a}}$ is unusually low (5.3). The low yield may thus reflect a poor nucleophilicity of the amino group, caused by the electron-withdrawing nature of the nitrile function.

Although the $\mathrm{pK}_{\mathrm{a}}$ of the amino group and the polarity of the carbonyl group of some of the secondary amines tested (e.g., proline amide, sarcosine methyl ester) was similar to that of amino acid amides, and thus seemingly suitable for efficient aminolysis, none of these compounds resulted in amide bond formation; it appears that the substituent at the $\alpha$-amino group prevents the kind of "productive binding « that is necessary for efficient acyl-transfer.

All these results indicate that the structural features that render the amino acid amides such outstandingly good amino components are a sufficiently nucleophilic primary amino group, an optimal polarity of the carbonyl group and the absence of substituents at the $\alpha$-amino- and/or the carbonyl group that would interfere with optimal binding either due to sterical hindrance or due to perturbations of weak, but crucial interactions depending on the correct polarity of the carbonyl group. However, the presence of a carbonyl group in the amine component is not necessary for aminolysis to occur. This is demonstrated by the high yields obtained with several primary amines.

Although the choice of amine components examined here was primarily guided by our wish to explore the use of CPD-Y for synthetic purposes, the observed dependence of yields on structure reveals interesting details about the active site region of this enzyme. For example, the fact that dipeptides are not incorporated, in conjunction with the earlier observation that an increase in the size of the alkyl ester group in $\alpha$ - amino acid alkyl esters results in drastically lowered yields (20), indicates that the size of the "carboxylate « binding region (Figure 2) of CPD. $\mathrm{Y}$ is very limited. Furthermore, if the polarity of the carbonyl group in $\alpha$-amino carbonyl type amine components is as crucial for optimal binding as we have interpreted it to be, then the presence of an equally as crucial enzymic group in the "carboxylate region must be assumed. In addition, the remarkable fact that isoglutamine did not react to form an amide bond, together with the observation that blocking its side chain (as amide or ester) resulted in good incorporation, indicates that the $S_{j}$-binding region may be a hydrophobic pocket (thus preventing the binding of an isolated charged group). Alternatively, assuming that this region of the active site is accessible to water, it is possible that the absence of coupling with glutamic acid and isoglutamine is due to repulsion from the presence of a negatively charged functional group in the $\mathrm{S}_{1}$-region of CPD-Y.

The above information (together with the results of BAI and HAYASHI (1) which suggest the presence of a sulfhydryl group at the $\mathbf{S}_{1}$-subsite) is of considerable interest from an enzymological point of view since this enzyme is still only poorly characterized. From the practical point of view, this knowledge of the active site structure of CPD-Y may be exploited to modify the enzyme in such a way as to specifically altering its structural specificity and/or its different catalytic activities.

\section{ACKNOWLEDGEMENTS}

We thank professor MARTIN OTTESEN for his continued interest and help in and with our work, and professor JOSEPH FRUTON for a preprint of his fortcoming review on enzymic synthesis of pepide bonds (5). The technical assistance of Mss. Bodil Corneliussen, PIA Poulsen and Merete SonNe is deeply appreciated. FRED WIDMER gratefully acknowledges the Swiss National Science Foundation for a Fellowship. 


\section{REFERENCES}

1. Bal, Y. \& R. Hayashi: Properties of the single sulfhydryl group of carboxypeptidase $Y$. Effects of alkyl and aromatic mercurials on activities toward various synthetic substrates. J. Biol. Chem. 254, 8473-8479 (1979)

2. Bergmann, M., Z. Zervas \& W. F. Ross: On proteolytic enzymes. VII. The synthesis of peptides of lysine and their behavior with papain. J. Biol. Chem. 111, 245-260 (1935)

3. Breddam, K., F. Widmer \& J. T. Johansen: Carboxypeptidase $\mathrm{Y}$ catalyzed transpeptidations and enzymatic peptide synthesis. Carlsberg Res. Commun. 45, 237-247 (1980)

4. Breddam, K., F. Widmer \& J. T. JohanSEN: Influence of substrate structure on carboxypeptidase $\mathrm{Y}$ catalyzed peptide bond formation. Carlsberg Res. Commun. 45, 361-367 (1980)

5. Fruton, J. S.: Enzymic synthesis of peptide bonds. In: Adv. Enzymol., A. Meister ed., John Wiley, New York (in press) (1981)

6. Fruton, J. S.: Chemical aspects of protein synthesis. In: The proteins. 2nd ed., H. Neurath ed., Academic Press, New York, Vol. 1, pp. 189-311 (1963)

7. Homanderg, G. A. \& I. M. Chaiken: Trypsincatalyzed conversion of staphylococcal nuclease$\mathrm{T}$ fragment complexes to covalent forms. J. Biol. Chem. 255, 4903-4909 (1980)

8. Komoriya, A., G. E. Homandberg \& I. M. Chaiken: Enzyme-catalyzed formation of semisynthetic staphylococcal nuclease using a new synthetic fragment, [48-Glycine] synthetic-(649). Int. J. Peptide Protein Res. 16, 433-439 (1980)

9. Levin, Y., A. Berger \& E. Katchalski: Hydrolysis and transpeptidation of lysine peptides by trypsin. Biochem. J. 63, 308-316 (1956)

10. Meyers, C. \& J. D. Glass: Enzymes as reagents in peptide synthesis: Enzymatic removal of amine protecting groups. Proc. Nat. Acad. Sci. USA 72, 2193-2196 (1975)

11. OfroRd, R. E.: Semisynthetic proteins. John Wiley, New York (1980)
12. Ohno, M. \& C. B. Anfinsen: Partial enzymic deprotection in the synthesis of a protected octapeptide bearing a free terminal carboxyl group. J. Am. Chem. Soc. 92, 4098-4102 (1970)

13. Oka, T. \& K. Morihara: Peptide bond synthesis catalyzed by thermolysin. J. Biochem., 88, 807$813(1980)$

14. Roberts, J. D. \& V. C. Chambers: Small-ring compounds. VII. Physical and chemical properties of cyclopropyl, cyclobutyl, cyclopentyl and cyclohexyl derivatives. J. Am. Chem. Soc. 73. 5030-5034 (1951)

15. Royer, P. G. \& G. M. Anantharmaiah: Peptide synthesis in water and the use of immobilized carboxypeptidase $\mathrm{Y}$ for deprotection. J. Am. Chem. Soc. 101, 3394-3396 (1979)

16. Schechter, I. \& A. Berger: On the size of the active site in proteases. 1. Papain. Biochem. Biophys. Res. Commun. 27. 157-162 (1967)

17. Tsuzukı, H., T. OKa \& K. Morihara: Coupling between Cbz-Arg-OH and Leu-X catalyzed by trypsin and papain. J. Biochem. 88, 669-675 (1980)

18. Waley, S. G. \& J. Watson: Trypsin-catalyzed transpeptidations. Biochem. J. 57, 529-538 (1954)

19. Widmer, F. \& J. T. Johansen: Enzymatic peptide synthesis. Carboxypeptidase Y catalyzed formation of peptide bonds. Carlsberg Res. Commun. 44, 37-46 (1979)

20. Widmer, F., K. Breddam \& J. T. Johansen: Carboxypeptidase $\mathrm{Y}$ catalyzed peptide synthesis using amino acid alkyl esters as amine components. Carlsberg Res. Commun. 45, 453-463 (1980)

21. Widmer, F., K. Breddam \& J. T. JohanSEN: Carboxypeptidase $\mathrm{Y}$ as a catalyst for peptide synthesis in aqueous phase with minimal protection. In: Proc. 16th European Peptide Symposium. K. Brunfeldt ed., Scriptor, Copenhagen pp. 46-55 (1981) 